\title{
DISTRIBUTION AND CONSERVATION STATUS OF THE MT MANGANA STAG BEETLE, LISSOTES MENALCAS (COLEOPTERA: LUCANIDAE)
}

\author{
by Jeff M. Meggs and Robert J. Taylor \\ (with one table, two text-figures and one plate)
}

\begin{abstract}
Meggs, J.M. \& Taylor, R.J., 1999 (31:x): Distribution and conservation status of the Mt Mangana stag beetle, Lissotes menalcas (Coleoptera: Lucanidae). Pap. Proc. R. Soc. Tasm. 133(1): 23-28. https://doi.org/10.26749/rstpp.133.1.23 ISSN 0080-4703. Forestry Tasmania, PO Box 343, Devonport, Tasmania, Australia 7310, formerly Forest Practices Board (JMM); Forestry Tasmania, 79 Melville Street, Hobart, Tasmania, Australia 7000 (RJT).
\end{abstract}

\begin{abstract}
Lissotes menalcas (the Mt Mangana Stag Beetle) is an obligate log-dwelling beetle and is presently classified as vulnerable under the Tasmanian Threatened Species Protection Act 1995. The distribution, habitat and conservation status of this species were investigated through a combination of collation of known locations and searches for the species in decaying logs across likely areas of occurrence. L. menalcas was found to have a wide distribution in southeastern Tasmania and is now recorded from 34 localities. The species was found in a variety of wet forest habitats from old-growth mixed forest through to 23 -year-old wet eucalypt silvicultural regrowth. About $12 \%$ of wet eucalypt forest within the predicted range of $L$. menalcas is formally reserved, and another $14 \%$ on Crown land is unlikely to be subject to logging. $L$. menalcas appears to tolerate both wildfire and clearfelling with regeneration burning. Because the species depends on an ongoing supply of rotting logs for its long-term survival, plantation development will probably lead to the elimination of the species from such areas. Analysis of the likely impact of plantation establishment within its range over the next ten years indicates that it will not reach levels that would lead it to be considered as vulnerable. Thus, it is recommended that the status of the species be changed from vulnerable to rare. However, there is a need to determine the ecological sustainability of present forest management practices in relation to the decaying-log habitat and to continue to monitor the extent of clearing and modification of the species' habitat.
\end{abstract}

Key Words: Lissotes menalcas, stag beetle, threatened species, conservation, plantations, wet eucalypt forest, Tasmania.

\section{INTRODUCTION}

The Mt Mangana Stag Beetle Lissotes menalcas Westwood is a large, black, flightless beetle, the males of which have large mandibles (pl. 1). Its body length varies between 16 and $25 \mathrm{~mm}$. It is endemic to Tasmania and readily distinguished from other Tasmanian lucanids by the following features: a highly polished exoskeleton, causing the males to appear as if coated with black enamel; a peculiarly shaped prothorax, with a humped or peaked appearance, and a largely excavated head (Lea 1910). The female is also highly polished but not as shiny as the male, due to the much denser and larger punctures on the head and prothorax. L. menalcas is a relatively long-lived beetle (five to six years, including larval stages - G. Bornemissza, pers. comm.). It is believed to spend the majority of its life within decaying logs feeding on wood-rotting fungi.

L. menalcas was first collected prior to 1855 (Westwood 1855). Previous to this study, it was only known from a handful of sites in southeastern Tasmania (Jackson \& Taylor 1994). L. menalcas was classified as vulnerable under the Tasmanian Threatened Species Protection Act 1995, due to the small number of recorded localities and its apparent disappearance from some of these localities, not having been re-collected from these since early this century.

Meggs (1996) has shown that first rotation logging has little influence on the size or quantities of decaying logs or the types of rot present. However, with successive rotations on an 80-year or shorter cycle, it is likely that the volume and size of logs available would decline. Studies in Europe and North America of sites which have been subject to intensive forest operations over several rotations have documented a dramatic reduction in the volume of rottinglog resource, particularly large diameter logs (Gore \& Patterson 1986, Andersson \& Hytteborn 1991) and

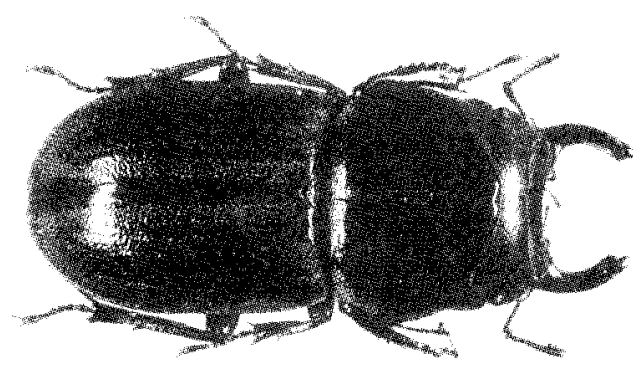

PLATE 1

Lissotes menalcas adult male, dorsal view (body length is $20 \mathrm{~mm}$, excluding the mandibles).

late-stage rottinglogs (Bader etal. 1995), which are important habitat for a number of beetle families including Scarabaeidae, Lucanidae and Passalidae (Harmon et al. 1986).

Given the cryptic habits of the species, it was suspected that it was probably more widespread than indicated by the available records. However, because of its log-dwelling habit and the potentially high proportion of its range occurring in wood-production forests, the species could be at risk. The present study was thus undertaken to reassess its distribution and conservation status.

\section{METHODS}

Records of the species were collated from museum and private collections. Fieldwork was conducted in southeastern Tasmania between November 1995 and April 1996 and in May 1998 at 43 sites. All sites searched were in wet eucalypt or mixed forest. These forest types were targeted so as to 


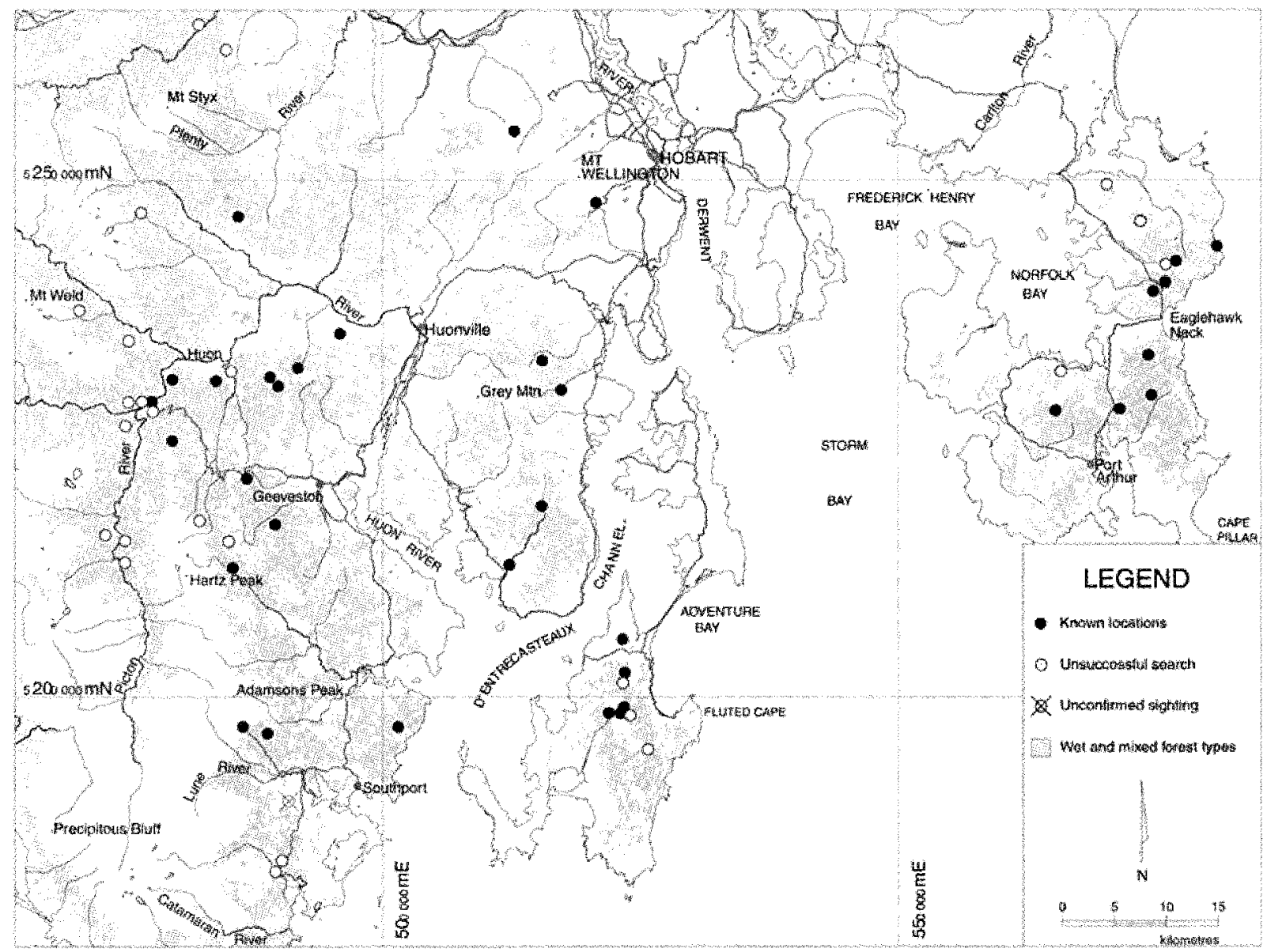

FIG. 1 - Known locations for Lissotes menalcas, sites of unsuccessful searches during this study and distribution of wet eucalypt forest in southeastern Tasmania.

maximise our chance of finding the species in an area. Rainforest was not searched, but the species is likely to occur in this forest type, as it has been found to occur in rainforest logs in mixed forest. We did not test our assumption that the species does not occur in dry forests but felt this was unlikely, given that all museum and private records were from wet forest.

Because of its cryptic habit, the sampling method used to locate L. menalcas was destructive and involved breaking open logs and searching the interior for adults. Logs lying on the ground as well as elevated logs of all sizes were searched. The only selection criterion used was that the exterior of the log exhibited signs of decay, including visible rot at the end or at a split, or a well-developed moss covering, suggesting that the log had been down for some time. More intensive searching was undertaken in those logs which contained moist red rot, a type of wood-decay which $L$. menalcas was thought to prefer (G. Bornemissza, pers. comm.). If white rot was encountered, the entire log was not searched, only the section that was broken. White rot tended to be either very fibrous or very wet and pulpy; hence, it tended to fall apart and did not require the detailed searching that red rot did. Sites were searched until L. menalcas was found or two hours had elapsed. Because of the destructive sampling method, no searches were permitted in reserves controlled by the Parks and Wildlife Service.
Traps were set at two known localities of $L$. menalcas in the southern forests, to determine whether standard pitfall trapping was a reliable sampling method for this species. Each trap consisted of a plastic cup (diameter $85 \mathrm{~mm}$ ) with ethylene glycol as a preservative placed inside a buried section of PVC pipe so that the rim of the cup was flush with the soil surface. Traps (16 at one site and 20 at the other) were set at least $2-3 \mathrm{~m}$ apart, as close as possible to decaying logs. Traps were left in place for 12 weeks from early December and were emptied at six weekly intervals.

Habitat data (vegetation, leaf litter, soil, geology, numbers and sizes of logs, slope, aspect, altitude, presence of fire scars on standing or fallen trees and any evidence of logging) were collected at all known localities of $L$. menalcas, except two sites that have been logged or burnt since the specimen was recorded, four without precise locality details, or one to which access could no longer be obtained.

The environmental modelling package CORTEX (Peters \& Thackway 1998), which has been derived from BIOCLIM (Busby 1991) and GARP (Stockwell 1993), was used to predict the potential area where suitable environmental conditions occurred for L. menalcas. Ten environmental variables determined at a scale of $1 \mathrm{~km}$ grid squares were used in the model: two temperature, two rainfall, soil nutrient level, geology, slope, aspect, topographic position and elevation. The model constructs environmental envelopes from combinations of ranges and/or categories 


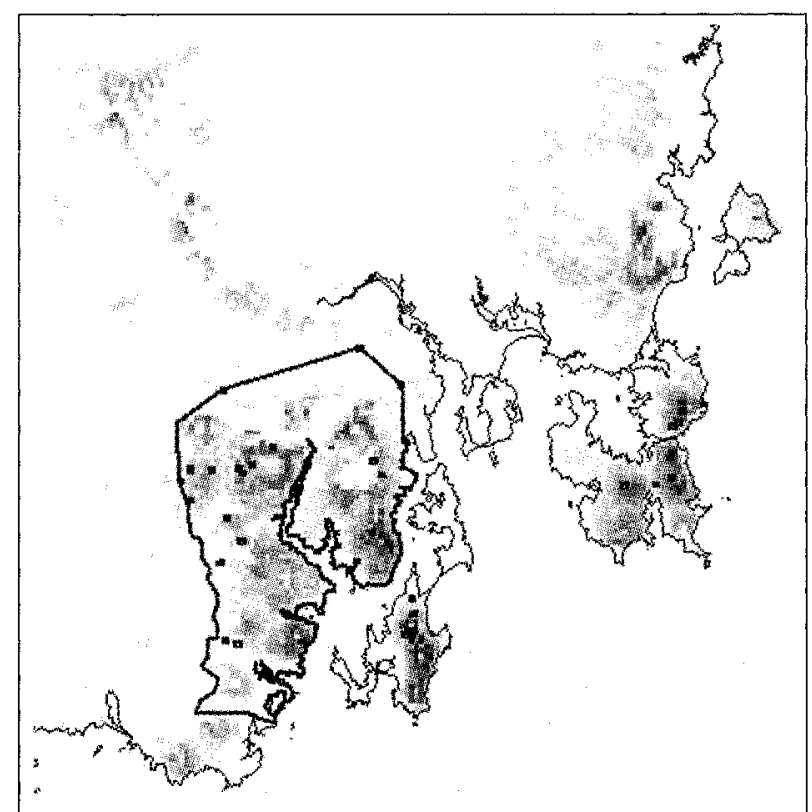

FIG. 2 - Predicted distribution of suitable environmental conditions for Lissotes menalcas in Tasmania from the CORTEX environmental modelling package. The darker the shade of grey the higher the predicted suitability of the environment. The black squares are known locations. Further sites of predicted suitability occurred in more northern areas of eastern Tasmania which are not shown. The black line represents the proposed limits of the predicted distribution in the mainland region.

of variables which imply the presence of the species. This analysis was undertaken in the Parks and Wildlife Service GIS section. The predicted range of the species was determined, based on the following: the results of the CORTEX model, the proximity to known locations, the presence of known sampling areas and the extent of suitable habitat present. The results of the CORTEX model were only used as one of the guides to predicting the distribution, as factors other than those used in the model may determine a species distribution. It is not uncommon for an invertebrate species not to occur in parts of the environmental range predicted by a CORTEX model, when these are searched for the species (Meggs 1999).

\section{RESULTS}

\section{Distribution}

Lissotes menalcas was found to have a wide distribution in southeastern Tasmania (fig. 1). In addition to the six localities known prior to this study (Jackson \& Taylor 1994), a further 12 records were obtained from private collectors and institutions, and another 16 were obtained by searching. $L$. menalcas has now been recorded at 34 localities, with an additional unconfirmed record from Ida Bay. This record was obtained from a list of Tasmanian Lucanidae produced by Barry Moore and provided to George Bornemissza. Locations were given, but grid references were not included. The discovery of this species on the Tasman and Forestier Peninsulas has extended its range east by just over $40 \mathrm{~km}$, representing a significant increase in its known distribution (fig. 1).
The extent of occurrence of $L$. menalcas, measured as the land area within the smallest convex polygon which contains all the sites of occurrence (calculated separately for the southern forests, South Bruny and the Tasman and Forestier Peninsulas combined), is $1831 \mathrm{~km}^{2}$. The CORTEX model (fig. 2) showed suitable environment for the beetle occurring in many areas well to the north and south of the known locations. Our conservative predicted extent of occurrence (fig. 2) was $3068 \mathrm{~km}^{2}$.

Pitfall trapping proved to be an unreliable method for sampling L. menalcas. During a 12 -week period, with a total of 36 traps laid at two localities at which the species was known to occur, only one female $L$. menalcas was trapped.

No data are available on population sizes. Three areas of high population densities in the Southern Forests were reported by private collectors. At these locations up to 10-12 L. menalcas have been found in a single log $(\mathrm{G}$. Bornemissza, M. Bouffard and A. Vanderschoor, pers. comm.).

\section{Habitat Requirements}

At sites where the species occurs, annual rainfall varies from just under $700 \mathrm{~mm}$ (on the Forestier Peninsula) to just over $1220 \mathrm{~mm}$ (in the Wellington Ranges). L. menalcas was found at altitudes up to $600 \mathrm{~m}$, but no sites over $650 \mathrm{~m}$ were searched in this study, although suitable vegetation occurs up to approximately $850 \mathrm{~m}$. Slightly less than half $(15$ out of 34 ) of the recorded localities of $L$. menalcas occur on Jurassic dolerite. The remaining records occur on a variety of sedimentary rock types. Soils were generally clay loams.

Leaf litter composition and depth varied greatly both within and between sites. L. menalcas was found in both wet eucalypt forest and mixed forest, but was found more frequently in the former ( $70 \%$ compared with $35 \% ; \chi^{2}=6.3$, $\mathrm{p}<0.05)$. Sites differed markedly in floristic and structural composition and successional stage (ranging from evenaged wet eucalypt regrowth forest to mixed age, late successional mixed forest). Sites were dominated by either Eucalyptus regnans, E. globulus or E. obliqua. L. menalcas was found in all three of the natural regrowth sites searched and three of the four silvicultural regrowth forest sites.

During this study, one female was found in white, pulpy rot inside a sassafras Atherosperma moschatum $\log$. All other L. menalcas found occurred in eucalypt logs, either just below the surface in slightly rotten logs or deep within the core of well-rotted logs. Generally the rot was a dark red and had a moist, clay-like consistency. This rot type does not appear to occur in rainforest trees. There was some variation in colour and wetness, from less moist orange-red rot through to saturated brown humus-like rot. However, only dead specimens were found in the latter. L. menalcas has also been collected from myrtle Nothofagus cunninghami logs (G. Bornemissza, pers. comm.) and from under wood debris in a sawdust mound at the site of an old timber mill (A. Vanderschoor, pers. comm.).

Three of the recorded localities were severely burnt in the late 1960 s by wildfire, which completely removed the canopy species present. At one of the sites, even small drainage lines and gullies appear to have been burnt, discounting the possibility of $L$. menalcas surviving in unburnt refuges. The silvicultural regrowth forest sites where $L$. menalcas was present would have been regenerated by a high intensity burn. 


\section{Distribution by Land Tenure and Land Use}

Twenty-three (68\%) of the 34 known locations for L. menalcas occur on land at present under the management of Forestry Tasmania. Seven of these are in areas which are, or are soon to become, dedicated reserves (Abel Tasman Forest Reserve, Tahune Forest Reserve, Mt Mangana, Hastings Caves-Southwest National Park extension, Lonnavale 1). Of the other known locations managed by Forestry Tasmania, nine are planned for wood production, one of which has been logged since the species was found there, and the remaining seven are in management zones protected from logging operations. Eight sites occur on private property. The remaining three sites are in reserves managed by the Department of Primary Industries, Water and Environment (Wellington Park, Snug Falls Nature Recreation Area).

The percentage of the habitat which is under different tenures or projected land uses is roughly comparable in the three major regions inhabited by the species (mainland, South Bruny, Tasman and Forestier Peninsulas), and so only the overall figures are presented in table 1 . The figures for rainforest are presented separately from wet eucalypt forest as, although some of these areas will support $L$. menalcas, it is unlikely that densities would be as great, due to the apparent preference of the species for eucalypt logs. Hence, the values for the wet eucalypt forests (which include sites with a rainforest understorey) are most relevant to assessing the amount and likely future of habitat of the species. These figures are derived from the vegetation mapping undertaken for the development of the Tasmanian Regional Forest Agreement and are applicable as at June 1996. Prior to this date, $35 \mathrm{~km}^{2}$ from the area of occurrence and $48 \mathrm{~km}^{2}$ from the predicted range had been converted to plantation on State forest and, hence, would not have been counted in the area of habitat figures in table 1 . All of these plantations have been established on sites formerly supporting wet forest. Between the time of the production of the forest vegetation map for the Regional Forest Agreement (June 1996) and March 1999, for wet forest habitat 431 ha within the area of occurrence and 905 ha within the predicted range were converted to plantation. Thus, to date, plantation development has reduced the area of wet eucalypt forest on Crown land by $5.4 \%$ in the area of occurrence and $5.0 \%$ of the predicted range from the Crown land estate. No estimates are available on how much habitat has been cleared from private land. $L$. menalcas has $134 \mathrm{~km}^{2}(12 \%)$ of wet eucalypt forest habitat reserved across its predicted range and a further $161 \mathrm{~km}^{2}(14 \%)$ in State forest which is unlikely to be subject to logging.

\section{DISCUSSION}

\section{Distribution}

This study has substantially extended the known range of L. menalcas in southeastern Tasmania to the Forestier and Tasman Peninsulas. The rediscovery of L. menalcas in the Wellington Ranges is important, as it had not been recorded there since early this century (Lea 1910). Together, these findings have increased the known range of the beetle by more than $25 \%$.

The distribution of $L$. menalcas may be greater than is currently known. The environmental domain for the species predicted from the CORTEX model indicated that a suitable environment exists in many areas outside the current known range. However, this study presents a conservative subset of this domain as a potential distribution for the species. This predicted distribution needs to be tested by further sampling of areas that the CORTEX model deemed to be environmentally suitable which we have not included.

On South Bruny Island and the Tasman and Forestier Peninsulas, all of the predicted areas were considered to be likely for $L$. menalcas. The predicted southern mainland boundary was conservatively taken to be the D'Entrecasteaux River, based on an unconfirmed record from Ida Bay. However, a suitable, predicted environment and habitat is present south of the D'Entrecasteaux River, and further searches could possibly find the species in this area. The ptedicted western boundary was determined on the basis of the known locations, the presence of suitable habitat and the climatic predictions. The predicted northern boundary was based on the known locations, as there was no evidence provided by the climatic model that they would occur further north in that particular region.

It is unlikely that the species occurs in the Wielangta area, as predicted by the CORTEX model, as much searching conducted by several investigators (J. Meggs, K. Michaels, G. Bornemissza, M. Bouffard, G. Blake, pers. obs. and pers. comm.) has failed to reveal its presence. However, the northwestern limit delineated in figure 2 could be extended with further searching. Although two searches in the Styx and West Uxbridge areas failed to locate the species, the Florentine and $\mathrm{Mt}$ Field areas remain to be searched.

To our knowledge, only one specimen additional to the one captured in this study has ever been caught in a pitfall trap. This was by R. Bashford (pers. comm.) in 1996 near the Kermandie River using the same type of pitfall as in our study. The very low capture success of these traps indicates that pitfall trapping is not a suitable means of sampling populations. In a study of the threatened stag beetle L. latidens in eastern Tasmania, Michaels (1996) also found lucanid species that were not captured in pitfall traps by searching for them in logs. Direct sampling appears to be the most reliable method available to locate L. menalcas. Unfortunately, the log-dwelling habit of $L$. menalcas makes direct sampling a destructive, time-consuming and serendipitous sampling method.

\section{Habitat Requirements}

Lissotes menalcas was found in a broad range of wet forest communities ranging from old-growth mixed forest to 23-year-old wet silvicultural regrowth forest. Because it was also found in rainforest species logs, albeit at lower rates than in eucalypts, it is highly likely that it also will occur in rainforest. Because L. menalcas is an obligate log-dweller, its occurrence and population density will be influenced by the size and abundance of logs and the extent and type of log decay. Further research is required to elucidate the particular microhabitat within decaying logs preferred by L. menalcas and to quantify differences in the availability of such microhabitat in forests of different types and ages.

In wet forests that L.menalcas inhabits, clearfelling followed by an intense regeneration burn is the standard silvicultural treatment. The species appears to be able to survive this type of disturbance. In the sites with silvicultural 
TABLE 1

The percentages of wet eucalypt forest and rainforest present in different land tenures and land use categories for the range of Lissotes menalcas

\begin{tabular}{|c|c|c|c|c|}
\hline & \multicolumn{2}{|c|}{ Wet eucalypt } & \multicolumn{2}{|c|}{ Rainforest } \\
\hline & $\begin{array}{l}\text { Known } \\
\text { extent }^{*}\end{array}$ & $\begin{array}{c}\text { Predicted } \\
\text { extent }^{\dagger}\end{array}$ & $\begin{array}{l}\text { Known } \\
\text { extent }\end{array}$ & $\begin{array}{c}\text { Predicted } \\
\text { extent }^{\dagger}\end{array}$ \\
\hline \multicolumn{5}{|l|}{ Percentage of habitat } \\
\hline \multicolumn{5}{|l|}{ Crown land } \\
\hline formal reserve & 11 & 12 & 46 & 65 \\
\hline not to be logged ${ }^{\ddagger}$ & 13 & 14 & 29 & 20 \\
\hline production forest & 51 & 49 & 23 & 14 \\
\hline Private land (\%) & 25 & 25 & 2 & 1 \\
\hline \multicolumn{5}{|l|}{ Area of habitat $\left(\mathrm{km}^{2}\right)$} \\
\hline mainland & 671 & 867 & 21 & 43 \\
\hline South Bruny & 2 & 72 & 0 & $<1$ \\
\hline Peninsulas & 45 & 193 & 1 & 1 \\
\hline Total & 718 & 1132 & 22 & 45 \\
\hline
\end{tabular}

\footnotetext{
* The extent of occurrence is the smallest convex polygon encompassing all of the known locations. Polygons were constructed separately for the three regions.

$\dagger$ The predicted distribution is based on the known locations, the extent of suitable habitat and the predicted occurrence of suitable environments from the CORTEX environmental modelling software.

¥ The area of Crown land not to be logged is made up of areas of State forest which are either informal reserves or have not been placed into coupes earmarked for production forestry.
}

regrowth, three of the four logs in which L. menalcas was located would have been present on the forest floor prior to logging. Most of the logs present as a result of logging did not appear to have decayed enough to have produced suitable habitat for $L$. menalcas. The protection afforded by the log habitat, at least in the larger logs, may be sufficient to insulate the species not only from the destructive effects of fire but also from the drying effects of the absence of a forest canopy in the years it takes a substantial canopy of regrowth to develop. However, the possibility of re-invasion of the logged area, following disturbance from logging and burning, cannot be ruled out. Anecdotal evidence that logdwelling fauna survive burning is provided by Mesibov (1988: 20):

In the course of my fieldwork I broke open literally hundreds of old eucalypt logs with jagged, burned ends and a hard, blackened surface, to find inside a mass of moist, unburned wood rot and a teeming community of invertebrates.

Fauna in the deep layers of soil are less affected by regeneration burning after timber harvesting than those in the litter (Vlug \& Borden 1973). The importance of refuges such as those under logs and stones to species survival in burnt areas has also been demonstrated (Madden et al. 1976). The interior of decaying logs may offer another such refuge. This may explain why the log-dwelling fauna of older regrowth and old growth are similar (Taylor 1990).

Plantation development in native forests will most likely lead to the local extinction of $L$. menalcas populations, due to the virtual elimination of rotting logs. Populations may survive in the short term in windrows (Bashford 1990). However, by the second rotation most of this resource has rotted away, with little to no replacement of the log resource from standing timber. Specific prescriptions for the sustainable management of the rotting-log resource are likely to be required where large areas of native forest are converted to plantation, in order to limit the impact of such practices on L. menalcas and other organisms associated with decaying logs.

\section{Conservation Status}

Lissotes menalcas is presently classified as vulnerable under the Tasmanian Threatened Species Protection Act 1995. The Tasmanian Threatened Species Advisory Committee has released criteria for use in assessing the conservation status of species (Threatened Species Advisory Committee 1998). These are similar to those adopted by the IUCN except that Tasmania uses an additional category, rare. If these criteria are applied to the current situation, the species does not warrant listing as endangered or vulnerable but does qualify as rare, because of the size of its range (less than $100 \mathrm{x}$ $100 \mathrm{~km}$ ) combined with the fact that threatening processes (plantation development and clearing of forest on private land) are operating. Some of the criteria for assessing conservation status relate to the predicted extent of loss of habitat over the next ten years. If a species will undergo a population decline of at least $20 \%$ within the next ten years, it is considered to be vulnerable. Forestry Tasmania has adopted a policy of increasing its rate of plantation establishment on State forest to compensate for the loss of resource following tenure changes under the Tasmanian Regional Forest Agreement. Current planning estimates from Forestry Tasmania indicate that less than $10 \%$ of wet 
eucalypt forest within the area of occurrence or within the predicted range will be converted to plantations over the next ten years. There is no indication of the future extent of loss of habitat on private land. However, the figure in Kirkpatrick (1991) indicates that clearing within the range of L. menalcas in the period 1980-88 was way below levels necessary to achieve a $20 \%$ reduction in $L$. menalcas habitat within the next ten years. It is recommended, therefore, that the status of the species under the Tasmanian Threatened Species Protection Act 1995 be changed from vulnerable to rare. However, given the restricted range of $L$. menalcas, monitoring of the impact of clearing and modification of habitat on the species should continue. This is particularly the case for private land where, unlike the situation on Crown land, no formal overview is being conducted. There is also a need to determine the effect of longer term ecological sustainability of native forest logging on the decaying log habitat. It is not known at present whether such habitat will be maintained after successive rotations of logging of native forest. Further assessment is also required of the effects of thinning of regrowth, a method increasingly being used to boost sawlog production from native forests.

\section{ACKNOWLEDGEMENTS}

This study was funded by the Australian Heritage Commission, the Forest Practices Board and Forestry Tasmania. Mark Wapstra, Daniel Vickers, Sarah Crute and Scott Barnes assisted with fieldwork. Collection records were provided by Mike Bouffard, Bob Mesibov, George Bornemissza, David Cowie, Andrew Vanderschoor and Dick Bashford. George Bornemissza and Andrew Vanderschoor also advised on sampling and provided information on the natural history of the species. The GIS section of the Parks and Wildlife Service ran the CORTEX modelling. Forestry Tasmania staff from Huon and Derwent Forestry districts assisted with access to and selection of sites. Data for table 1 was provided by Marco Giana and Luke Ellis of Forestry Tasmania. Bill Brown provided the photo of $L$. menalcas. Sarah Munks commented on a previous draft of this paper.

\section{REFERENCES}

Andersson, L.I. \& Hytteborn, H., 1991: Bryophytes and decaying wood - a comparison between managed and natural forest. Holarct. Ecol. 14: 121-130.

Bader, P., Jansson, S. \& Jonsson, B.G., 1995: Wood-inhabitating fungi and substratum decline in selectively logged boreal spruce forests. Biol. Conserv. 72: 355-362.

BASHFORD, D., 1990: The dispersal of ground beetles into different aged eucalypt plantations in north eastern Tasmania. Tasforests 2: 43-51.

BusBY, J.R., 1991: BIOCLIM - A bioclimate analysis and prediction system. In Margules, C.R. \& Austin, M.P. (Eds): NATURE CONSERVATION: COST EFFECTIVE BIOLOGICAL SURVEYS AND DATA ANALYSIS. CSIRO, Melbourne: 64-68.
Gore, J.A. \& Patterson, W.A., 1986: Mass of downed wood in northern hardwood forests in New Hampshire: potential effects of forest management. Can. J. For. Res. 16: 335339.

Harmon, M.E., Franklin, J.F., Swanson, F.J., Soldins, P., Gregory, S.V., Lattin, J.D., Anderson, N.H., Cline, S.P., Aumen, N.G., Sedell, J.R., Lienkaemper, G.W., Cromack, K., Jr \& Cummins, K.W., 1986: Ecology of coarse woody debris in temperate ecosystems. Adv. Ecol. Res. 15: 133-302.

JACKSON, J. \& TAYLOR, R., 1994: THREATENED FAUNA MANUAL FOR PRODUCTION FORESTS IN TASMANIA. Forestry Tasmania, Hobart.

KirKPATRicK, J., 1991: The magnitude and significance of land clearance in Tasmania in the 1980s. Tasforests 3: 11-14.

LEA, A.M., 1910: Notes on the genus Lissotes, with descriptions of new species. Pap. Proc. R. Soc. Tasm. 1910: 346-366.

Madden, J.L., Hickman, J.L., Richardson, A.M.M. \& Hill, L., 1976: Effect of cutting and regeneration practice on the invertebrate fauna of litter and soil. WOODCHIP SYMPOSIUM PAPERS, 47th ANZAAS CONGRESS. Tasmanian Forestry Commission, Hobart.

MEgGS, J.M., 1996: PILOT STUDY OF THE EFFECTS OF MODERN LOGGING PRACTICES ON THE DECAYING-LOG HABITAT IN WET EUCALYPT FOREST IN SOUTH-EAST TASMANIA. Regional Forest Agreement - Tasmania. Forestry Tasmania, Hobart: $75 \mathrm{pp}$.

MEGGS, J.M., 1999: Surveys for Lissostes latidens (broad-toothed stag beetle) in priority coupes on the Forestier and Tasman Peninsulas. Unpubl. rep. For. Tasm., Hobart: 10 pp.

Mesibov, R., 1988: Tasmanian Onychophora. Unpubl. rep. Dep. Lands, Parks Wildl., Hobart: 44 pp.

Michaels, K., 1996: The occurrence of the endangered stag beetle Lissostes latidens (Westwood) (Coleoptera: Lucanidae) in selected areas in the Wielangta Forest Block, Tasmania. Unpubl. rep. For. Tasm., Hobart: 7 pp.

Peters, D. \& THACKWAY, R., 1998: A NEW BIOGEOGRAPHIC REGIONALISATION FOR TASMANIA. Rep. Nat. Heritage Trust, Tasm. Parks Wildl. Serv., Hobart

STOCKWFll, D.R.B., 1993: A computational and theoretical basis for fauna modelling. Unpubl. rep. Tasm. Parks Wildl. Serv., Hobart.

TAYLOR, R.J., 1990: Occurrence of log-dwelling invertebrates in regeneration and oldgrowth wet sclerophyll forest in southern Tasmania. Pap. Proc. R. Soc. Tasm. 124: 27-34.

Threatened SpeCies AdVISORY COMmITTEe, 1998: GUIDELINES FOR THE LISTING OF SPECIES UNDER THE TASMANIAN THREATENED SPECIES PROTECTIONACT 1995. Department of Environment and Land Management, Hobart.

Vlug, H. \& Borden, J.H., 1973: Soil Acari and Collembola populations affected by logging and slash burning in a coastal British Columbia coniferous forest. Environ. Entomol. 2: 1016-1023.

WESTWOOD,J.O., 1855: Descriptions of some new species of exotic Lucanidae. Trans. Entornol. Soc. Lond. 3: 197 221.

(accepted 29 March 1999) 